Portland State University

PDXScholar

5-1975

\title{
A Descriptive Study of Previously Institutionalized Educable Mentally Retarded Adults Residing in Multnomah County, Oregon
}

\author{
Susan J. Kiley \\ Portland State University \\ Jeffrey D. Sher \\ Portland State University \\ Richard C. Sunshine \\ Portland State University
}

Follow this and additional works at: https://pdxscholar.library.pdx.edu/open_access_etds

Part of the Social Work Commons, and the Special Education and Teaching Commons Let us know how access to this document benefits you.

\section{Recommended Citation}

Kiley, Susan J.; Sher, Jeffrey D.; and Sunshine, Richard C., "A Descriptive Study of Previously Institutionalized Educable Mentally Retarded Adults Residing in Multnomah County, Oregon" (1975). Dissertations and Theses. Paper 1912.

https://doi.org/10.15760/etd.1911

This Thesis is brought to you for free and open access. It has been accepted for inclusion in Dissertations and Theses by an authorized administrator of PDXScholar. Please contact us if we can make this document more accessible: pdxscholar@pdx.edu. 


\title{
A DESCRIPTIVE STUDY OF PREVIOUSLY INSTITUTIONALIZED EDUCABLE MENTALLY RETARDED ADULTS RESIDING
}

IN MULTNOMAH COUNTY, OREGON

\author{
Susan J. Kiley \\ Jeffrey D. Sher \\ Richard C. Sunshine
}

A practicum submitted in partial fulfillment of the requirements for the degree of

MASTER OF SOCIAL WORK

Portland State University

1975 
TO THE OFFICE OF GRADUATE STUDIES :

The members of the Committee approve the practicum of Susan Kiley, Jeffrey D. Sher, and Richard C. Sunshine, presented May, 1975.

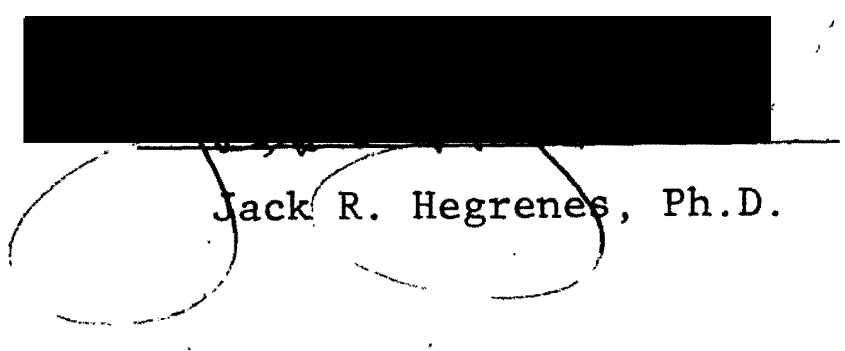

APPROVED :

Dr. Gordon Hearn, Dean of the School of Social Work

May, 1975 


\section{ACKNOWLEDGEMENTS}

The authors of this report wish to acknowledge the support and assistance provided by the following persons and organizations, without which this project could not have been completed. We were encouraged and supported by Dr. Larry Talkington, administrator of Fairview Hospital and Training Center, who patiently met with us and conferred on the design of the study. Mr. Dennis Heath of Fairview was also especially helpful. The Multnomah Association for Retarded Citizens generously supplied a small research grant to aid in the producing of this report. Mr. Walter Fuerher, director of MARC, and his staff were always willing to answer our questions, meet with us, and provide encouragement and expertise. Our special thanks go to Ms. Charlotte Duncan of MARC and Ms. Ethelyn Gardiner, Area Service Coordinator for Developmental Disabilities, who each spent many hours with us and provided thoughtful assistance. Our advisor, Dr. Jack Hegrenes, was a source of constant support and helpful criticism from the inception of this project to its conclusion.

Finally, we wish to acknowledge and thank the retarded adults who allowed us to enter into their worlds ever so briefly, and who are the substance and spirit of this report.

$$
\text { S.K. J.S., R.S. }
$$


TABLE OF CONTENTS

Acknowledgements............................

Introduction......................... 1

Design and Implementation........................ 15

Interview Guide....................... 15

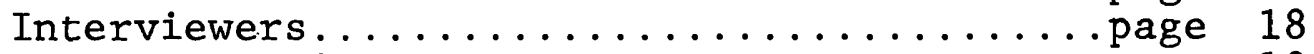

Data Processing............................... 18

Population............................ 19

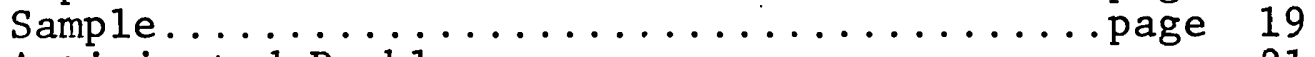

Anticipated Problems............................. 21

Implementation........................... 24

Results.................................. 26

Demographic Characteristics...........page 27

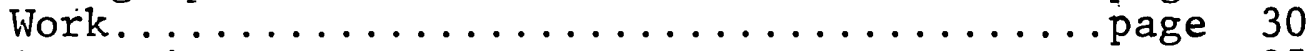

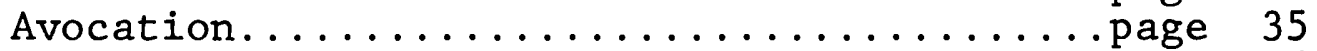

Interpersonal Relationships............page. 36

Dependence/Independence......................... 38

Three Retardates in the Community...........page 43

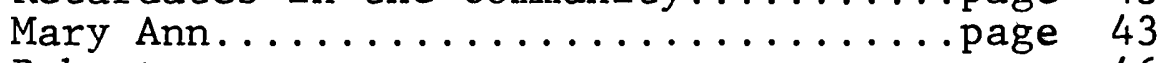

Roberta................................ 46

Fred............................... 49

Conclusions and Implications.................... 56

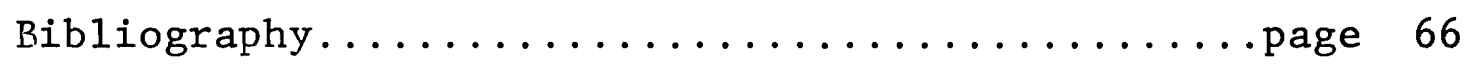

Appendix................................ 74 


\section{LIST OF TABLES}

Number

Title

Page

Table I

Levels of Measured Intelligence

Table II

Characteristics of the Cohort

Table III

Characteristics of the Sample

Table IV

Living Arrangements of the Sample

Table V

Current Employment Status

Table VI

Length of Time on Current Job

Table VII

How to Find a New Job

Table VIII Response to Illness on Job

Table .IX

Handling of Paycheck

Table X

Rank Ordering of Worker Attributes

34

Table XI

Contact With Neighbors

Table XII

Family Visitation

Table XIII

Assessment of Dependent to Independent Functioning

Table XIV

Duration of Community and Institutional Residence Related to Independent Functioning

Table XV Assessed Independence-Dependence Compared to Living Situation 


\section{INTRODUCTION}

"Just listen to her. She is really telling it like it is. Can you believe we are here?" (Comment overheard at People's First Convention, Otter Rock, Oregon, 1974.)

This is a study of mild and borderline mentally retarded adults living in Multnomah County, Oregon, who at one time in their lives were patients at Fairview Training School. As the above quote and the event (People's First a conference put together by and for mentally retarded adults) indicates, we are at the beginnings of a new era in dealing with mental retardation. The concept of 'normalization' is merging with the political necessity of 'advocacy' to create a different role for the traditionally silent and previously institutionalized retarded citizen, along with new roles for the professional worker with the retarded. As Gozali (1971) notes:

In the past few years, national concern with the plight of the minority groups and the poor in our society has redirected the attention of some workers to the quality of life that many adjusted, mentally retarded persons lead in the community. (1)

Mentally retarded citizens have only recently begun to speak out for themselves; even less frequent it seems, has been any concerted listening on the part of the public or the professional community which deals day to day with the 
retarded citizen in the community. This study represents some first steps toward listening to the retarded citizen's new voice, toward a more humanistic appraisal of the life styles of this group.

We have been concerned with the elusive concept of dependent versus independent living in the day to day life of this population, i.e., Educable Mentally Retarded (EMR) adults. Since very little is known about this population in our community, our effort can be considered an exploratory descriptive study of the life styles of mild/borderline previously institutionalized adults.

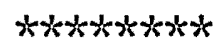

In Oregon, as in the rest of the country, there has been a change in approach to the problem of mental retardation in recent years. Societal responses to the retarded have, until recently, focused on the differences between them and the 'normal' population. This policy led to special treatment and training in special settings. These settings, whether labeled training school, asylum, hospital, or the generalized term 'institution,' all have practiced an admixture of custodial and rehabilitative functions, addressing themselves to an extremely heterogeneous population, ranging from the profoundly mentally and physically disabled to, until recently, borderline retarded individuals with contingent emotional and psychiatric disabilities. The significant thrust of change in the response to 
mental retardation has been to 1. ) reduce the size of the institutionalized population by looking for community based treatment facilities, 2.) focus on the potential for normal behavior rather than the differences from normal. This new general approach, known as 'normalization' is defined by Wolfensberger (1972) as:

Utilization of means which are as culturally normative as possible in order to establish, and/or maintain personal behaviors and characteristics which are as culturally normative as possible. (2)

The State of Oregon Comprehensive Developmental Disabilities Plan (1972) reflects this principle of normalization in stating as a primary goal: "(to) Train, educate and habilitate the mentally retarded to a degree consistent with their capacities in order that they may achieve maximum self-sufficiency. $*(3)$

A number of policy shifts have occurred in Oregon over the past ten years. An assumption is that maximum selfsufficiency can be attained by mild and borderline adults more efficaciously in the community than in large institutions. This results in more EMRs being moved from the institutions into the community now, and a probable trend for more Trainable Mentally Retarded (TMR) in the near future. This reflects the belief that TMRs can also achieve maximum self-sufficiency through social integration rather

* It should be noted that this plan was developed in order to be eligible for federal funding, and thus is a reflection of national policy toward retardation. 
than institutionalization. Institutionalization will be the treatment of choice only for the profoundly retarded. Although this population of mental retardates in the community is increasing and will increase, there is, as Tarjan et. al. (1973) note, "practically no information available concerning the adjustment of the retarded in the community."(4)

While there haf been a considerable number of followup studies of the mentally retarded in the community (e.g., Fairbanks - 1933; Baller - 1936, 1939; Jewe11 - 1941; Muench - 1944; Abel - 1945; Charles - 1953; Dinger - 1961; Kennedy - 1962; Miller - 1965), there seems to be little consistency in the findings. As Katz (1968) points out, the findings are, in fact, contradictory. For example, in one review of the literature, Windle:

Came to the disappointing conclusion that little could be generalized from the extensive literature on the subject ... On the other hand, after reviewing many follow-up studies of the social and occupational adjustment of mentally retarded persons who had been in state institutions, Goldstein concluded that a large majority of the retarded patients released had made a generally successful community adjustment. (5)

Katz also reports a study by Miller which indicates that former patients have a difficult time in the community. (6) What all of these studies have in common, despite their contradictory findings, is that they do not take into account the point of view of the retarded person 
herself.* In a recent study, Henshel (1972) succinctly summarized the situation by stating:

Examination of the literature on the EMR had revealed that the majority of studies were conducted from a single perspective, primarily from official files and via the opinion of virtually everyone but the individuals investigated. Parents and psychologists, counselors and teachers, - all congregated, in the literature, to explain the retardate's problems, attitudes, and, more rarely, joys. Few studies indeed had extended the subjects the opportunity to discuss their life experiences from their own point of view. (7)

It was from precisely this point of view, i.e., to extend to mentally retarded adults the opportunity to discuss their life experiences, that we undertook this study. Consultation with professionals in the community who work with the retarded (Multnomah Association for Retarded Citizens, Child Development and Rehabilitation Center staff, Service Coordinator for Developmental Disabilities, Fairview administration and field staff) indicated a local need and interest in a study of adults living in the community. The earlier referred to People's First Convention occurred as we were planning the design of this study and lent further impetus to a study which would take into account the perspective of the retardate himself. It was as guests to this event that we first heard mentally retarded adults express their own perceptions of their world, their frustrations, their joys and their needs.

* Throughout this report, use of male and female pronouns is interchangeable. 
For the past several years there has been a steady flow of retarded persons to the Multnomah County area - estimated at approximately 130 per year* - from Fairview Training School and Hospital. Multnomah County, which is the largest metropolitan area in the state, is recognized as a major provider of service to the developmentally disabled which include the mentally retarded. Figures from the State of Oregon Developmenta1 Disabilities P1an state that approximately 3,000 mentally retarded individuals are served in Multnomah County each year. (8) Because the nature of service provision is on an individual basis, i.e., a casework model, professionals in the community have specific knowledge of individual retarded citizens and their functioning. However, a consistent professional concern was with the lack of a more general population description, especially for EMR adults.

Given our understanding of the kind of research that had previously been conducted on EMR adults, and the needs expressed by the professional community, we decided to conduct a study which would have as its focus the day to day life of the retardate as she experiences it. In this study we therefore used the self-report ${ }^{* *}$ of the individual interviewed as the primary source of data, in an attempt to formulate a personalized view of her life.

* Personal communication from Area Service Coordinator. ** For a critique of some of the problems of self-report as a source of data, see Selltiz et al (1959), p. 236-237. We anticipated additional problems which are discussed more fully in the design section of this paper. 
Besides producing a purely descriptive study of the populaticn, we hoped to identify problems that people had in the cormunity, in order to share this knowledge with the appropriate professionals. We did not focus on the existing gaps and lacks in the service network, but rather attempted to assess the individual's preparation and individual coping abilities in his environment, as it exists; i.e., her ability to use those resources that do exist. We also were receptive to any needs and difficulties which they experienced in their day to day life. Another practical aspect of the research, which we had not anticipated at its inception, became the task of unifying the various lists of people reported to be in the community. This was done in conjunction with the Service Coordinator and the Fairview Field Workers.

\section{$* * * * * * * * *$}

As noted previously, there is a paucity of literature dealing with the mentally retarded in the community from the perspective which we attempted. However, two studies were of particular importance to us, both. in terms of the ideas for the design of our study, and in terms of the particular stance, i.e., their value orientation, which was especially influential to us.

Edgerton's classic study The Cloak of Competence (1967) was the first attempt to enter into the culture and the world of the mental retardate, and to attempt to experience 
that world through his senses. Edgerton's background as an anthropologist gives his study a uniquely intimate and in depth view of 'life on the outs.'

The other study, to which we previously referred, is Henshel's more recent study titled, The Forgotten Ones - A Sociological Study of Anglo and Chicano Retardates (1972). On a much smaller scale, we adopted much of the design of the Henshel study for use in this project. Our indebtedness to both of these studies is considerable and their influence in our thinking pervasive.

One clear example of this influence is in the areas of concern on which we focused in our interviews. As Edgerton stated:

Both the important commonality and the variability in their lives can be understood by concentrating on those dimensions of life that the expatients themselves saw as being either critical to their ability to exist 'on the outs' or as a foci upon which their interests and energies centered. By these criteria there were three central concerns: 1 . How to make a living, 2. The proper management of sex, marriage and reproduction, and 3 . the ways in which leisure can best be utilized. (9)

For our purposes we called these areas work, avocation and interpersonal relations, also allowing for some overlapping of these categories.

We were searching both for a description à la the anthropological/sociological style of Edgerton and Henshel, and for unmet needs of the educably retarded in our community as expressed by the retardate. As Katz (1968) states: 
There has been 1ittle systematic study of the retarded adults expressed needs. The ideal way to determine these needs would be to obtain the information directly from the retarded adult himself, and whenever possible this method should be used. There are many limitations to such an approach. Many retarded have poor comprehension or distorted ideas of what their needs are, based on incorrect knowledge or inadequate judgement. There are many who cannot express themselves verbally and cannot state what they need. In many instances, it is the parents and guardians who express what they believe the retarded adult needs, and this may represent what the parent needs rather than what the retarded person needs. (10)

It was in this spirit that we undertook this study - to hear what the mentally retarded adult experiences and what he perceives as his needs.

$* * * * * * * * *$

We will conclude this section with some definitions of the major terms and concepts utilized in the study: namely, mental retardation, independence/dependence, work, avocation, and a differentiation of the respondents' living arrangements.

This study was conducted with people who had in their lives been judged mentally retarded or mentally deficient, and who had been placed for training in the Fairview Hospital and Training Center. Thus, in our formulations and design of this study, the question what is a mentally retarded person was a given the population already having been diagnosed. We therefore accepted the clinical definition of mental retardation as our model. This point of view is exemplified by the standards set by the American Association on Mental Deficiency (AAMD). Katz relies heavily 
on this model in his definition of mental retardation:

The AAMD has defined individuals subaverage general intellectual functioning as performance which $1 \mathrm{~s}$ more than one standard deviation below the population mean of his own age group. To characterize the relative degree of severity of impairment in general functioning, an individual may be classified in one of the five levels of subaverage general intellectual functioning: borderline, mild, moderate, severe, and profound - depending on his intelligence test score expressed as an I.Q. score....Table I presents the level of measured intelligence for intelligence test scores characterizing subaverage general intellectual functioning.

Table I

Levels of Measured Intelligence*

\begin{tabular}{|c|c|c|c|c|}
\hline \multirow[t]{2}{*}{ Levels } & \multirow[t]{2}{*}{ Description } & \multirow[t]{2}{*}{$\begin{array}{l}\text { Range in } \\
\text { SD Units }\end{array}$} & \multicolumn{2}{|c|}{ I.Q. Range } \\
\hline & & & $\begin{array}{l}\text { Wechsler/ } \\
\text { Bellevue }\end{array}$ & $\begin{array}{c}\text { Stanford } \\
\text { Binet }\end{array}$ \\
\hline $\begin{array}{r}\text { I } \\
\text { II } \\
\text { III } \\
\text { IV } \\
\mathrm{V}\end{array}$ & $\begin{array}{l}\text { Borderline } \\
\text { Mild } \\
\text { Moderate } \\
\text { Severe } \\
\text { Profound }\end{array}$ & $\begin{array}{l}-1.01 \text { to }-2.0 \\
-2.01 \text { to }-3.0 \\
-3.01 \text { to }-4.0 \\
-4.01 \text { to }-5.0 \\
\text { below } 5.0\end{array}$ & $\begin{array}{c}70-84 \\
55-69 \\
40-54 \\
-\end{array}$ & $\begin{array}{l}68-83 \\
52-67 \\
36-51 \\
20-35 \\
\text { below } 20\end{array}$ \\
\hline
\end{tabular}

*Adapted from Heber (1961) (11)

The population which we sampled was all in the first two categories, namely borderline and mild.

The second consideration in a clinical approach to the question 'what is mental retardation?' is concerned with impairment in adaptive behavior. Katz defines adaptive behavior as "a complex process involving learning abilities and social adjustment". (12) He goes on to quote from Heber as follows : 
Learning ability refers to the facility with which knowledge is acquired as a function of experience ... Social adjustment... at the adult level... is assessed in terms of the degree to which the ind1vidual is able to maintain himself independently in the community and in gainful employment as well as by his ability to meet and conform to other personal and social responsibilities and standards set by the community. (13)

Thus, those people who are actively identified as mentally retarded are judged so based both on intellectual functioning (IQ) and adaptive behavior functioning, although definition and measurement of this factor are still being developed. Both of these determinants of the label, 'mentally retarded', are strictly clinical, and in our study we utilized these definitions.

However, it should be noted that there is a different school of thought, the social system perspective, on the phenomenon of mental retardation, especially as it would apply to the more borderline and mild forms which do not manifest organic, biological pathology. Mercer (1973), a leading exponent of this viewpoint, states, "From a social system perspective, 'mental retardate' is an achieved social status and mental retardation is the role associated with the status."(14)

While it is beyond the scope of this study to encounter these definitional problems, it should be realized that the phenomenon of mental retardation is not subject to simple definition, epidemiology or etiology; and that, indeed, a relativistic view is perhaps necessary to begin to formulate relevant research questions. Mercer's 
critique of the limitations of a purely clinical perspective is telling and poses important methodological questions to the researcher. As she states:

The intellectual problem of mental retardation in the community is, ultimately, a problem of classification and nomenclature. The perspective from which human behavior is viewed determines its meaning, (15)

For this study, in summary, mental retardation is viewed in terms of a clinical perspective. Additionally, each individual had at one time in her life occupied a formal status as a mentally retarded person at Fairview Hospital.

Edgerton in his classic study stated:

No effort was made to define independence precisely - the working definition was simply a subjective judgement of the extent to which the person was living without the need for assistance from others. (16)

We attempted in this study to delineate with some precision and reliability the relative independence/dependence of our sample. The conceptualization utilized by Bjaanes and Bulter (1974) in their study of care facilities became the basis for our observations and served as our definition as we11:

Independent-dependent: where independent was defined as an activity in which the individual was dependent on himself for cues, guidance and judgement in the performance of the activity. Dependent was defined as an activity in which the retarded person was dependent upon another person for guidance, cues and judgement in the performance of the activity. (17) 
The difficulties of making these judgements, even with the guidelines outlined, will be discussed in the body of this report.

Work is defined as the structured activity in a job setting, with payment for services, as usually understood; and also for those activities which the retarded person considers as her work, irregardless of payment. This might be a sheltered workshop or some other program which might not be included in a normal understanding of work. Community workers with the retarded stressed the importance of including these other activities which the retarded person considers her work or training.

Avocation is the sum of leisure time activities which have a specific structure or form, i.e., going to dances, going fishing, drawing, as opposed to sitting at home watching television - which is certainly an activity but not an avocation by our definition.

A group home is a living arrangement wherein more than one retarded person resides under the supervision of paraprofessionals. This home may be independently operated or under the auspices of a social agency.

Family living is defined as a situation in which the retarded person lives with his family of origin, and supervision is provided by parents.

A foster home living situation is defined as one in which the retarded person lives as a member of a family, in the style of family living, but 'parental' supervision 
is provided by paraprofessional foster parents designated and paid by an agency for the care they provide. Independent living is defined as a situation in which the individual lives alone, or with a spouse if married, in an apartment or house, and does not recieve day to day supervision from any outside source. $* * * * * * * * * *$

This concludes our in troduction. The remainder of this report consists of chapters on design and implementation, report of the data, and conclusions and implications. An appendix is also included and contains the interview guides and other pertinent material. 


\section{DESIGN}

\section{Interview Guide}

In order to describe the sample retardate population, to examine the state of community functioning, and to gain a sense of the dependent/independent functioning of the retarded person, the areas of work, avocation and interpersonal relations were explored.

The members of this project held a series of consultation meetings with Portland area Fairview field workers, social workers from the Multnomah Association for Retarded Citizens, staff persons from the University of Oregon Child Development and Rehabilitation Center, and other persons who work directly with retarded persons. Following these consultations, questions were constructed for each of the three areas. These questions were subsequently critiqued for revisions.

In order to test the efficacy of the interview guide and the introductory format, names were obtained of three retarded adults who closely fit the criteria of the population, but had never resided in Fairview. Each of the members of the research team then selected one of the three areas of the interview guide, and conducted a trial interview. From this pretest, it was determined which questions seemed 
to work and which questions needed reworking. These trial interviews also served to sensitize the interviewers to some of the complications which might arise in the interview process.

Not only developing the questions, but also deciding how to present the questions seemed a crucial area for consideration. It was decided to conduct three one-hour interviews with each member of the sample. It was assumed that in the process of conducting the interviews, a relationship would be formed with the interviewee. The first interview session, therefore, would probably be most productive if it was limited to questions focused on the less personal areas of work and work related matters. By the second interview, it was assumed that the interviewer and the interviewee would have formed a relatively more familiar and trusting relationship. The questions concerning avocational activities and personal interests seemed more likely to be received and openly responded to. It was concluded that questions concerning personal relationships and family would consequently be most easily discussed in the third and final interview. Although it was concluded that this structure would generally be the best presentation format, it was decided to ultimately follow the interests of the interviewee. For example, if she were sharing information on personal relationships during the second interview, the interviewer would pick up on her verbalized and affective content, and include questions at the time which seemed 
most confortable and approrpiate for the individual respondent.

The questions for each of the areas of work, avocation and interpersonal relationships were intended to be flexible, as was the timing of their presentation. The questions for each area were meant to serve as guidelines. The researchers realized that for each respondent, these questions would have to be adapted and also presented in a language and style which the individual interviewer felt would most likely lead to a full and comfortable response. The interviewer would utilize the information he was hearing from the respondent to make further inquiries more specific to the individual's setting. As an example, if the respondent mentioned the name of his supervisor and the location of his employment, these specifics would then be used in asking further questions about job related situations .

The follow-up questions which used specifics provided by the interviewee were designed not only to allow the interviewee to offer more situation specific replies and amplifications, but also to check for consistency of response. By using several types of questions, all of which aimed at specific sub-areas of inquiry, we hoped to determine the subject's consistency on how he described his perceptions of feelings and behaviors. We would also know how clearly he understood our questions. This procedure served as a reliability test. 
Selltiz comments that any interview guide or research technique which depends upon the self report of the respondents will have biases and weaknesses. (18) In Henshel's study, it was noted that the discrepancies in a retarded adult's self reported perceptions and feelings would surely present a problem for researchers attempting to quantify their data. However, as Henshel noted, these discrepencies in the retardate's perceptions reflect that person's point of view of the world, and his position in the world. In other words, discrepency in the self reported information must be accepted and worked with, for it likely represents the person's view of himself and the world around him. (19)

\section{Interviewers}

Interviewing was done by the three authors of this study, two white males and one white female, all in their late $20^{\prime} \mathrm{s}$. Each interviewed both male and female subjects, with subjects assigned to interviewers according to geographical proximity of their respective homes. Each interviewer identified himself as a graduate student at Portland State University, conducting research for the purpose of fulfilling requirements for a Master's degree in social work.

\section{Data Processing}

Interview data was processed in two ways: taperecording of interviews and the use of a post interview 
checklist. At the onset of the first contact with a respondent, it was explained that in order to make it easier to listen and to later tabulate data, taperecording of the sessions was desired. The confidentiality of these tapes was explained thoroughly. All but two of the twelve respondents consented to the recording of our meetings. Immediately following each interview, the interviewer completed an interview guide checklist (see appendix). This checklist was used to immediately record impressions and perceptions of the categories of information which the open-ended questions helped generate.

\section{Population}

The population under study was borderline and mildly mentally retarded adults between the ages of 18 and 40, residing in Multnomah County, who had been previously institutionalized at Fairview Hospital and Training Center, and who had returned to the community between January 1 , 1969 and December 31, 1974.*

Sample

The population described above was estimated by

* It should be noted that there have been programs for Educable Mentally Retarded in the community provided by the school system for many years. It may be concluded that the population under study had additional problems in adaptive and social functioning which led to their institutionalization rather than integration through the community. Presently the EMR's would not, except in extreme cases, be institutionalized. 
Fairview and MARC professionals to number approximately 300 . Since it would have been impossible, within the scope of this study, to interview the entire population, it was decided to extract a simple random sample of 30 individuals, 10 percent of the population.

The first step in sample preparation involved enumerating the population. This was begun by obtaining a printout, from Fairview, of all persons released from the institution between 1969-1974. The printout contained information as to the birth date, AAMD level, date of admission to Fairview, date of release to the community, and county to which each individual was released. Not all of this information was always present for each individual, however. From this master 1ist, the names of all those persons who met the criteria for the study were extracted. This cohort consisted of 85 individuals.

The researchers had been cautioned by professionals that there is a certain amount of mobility among retarded persons released from Fairview, and that some persons released to a county other than Multnomah might have moved to Multnomah County since release. In order to include these people in the cohort, lists of all retarded persons receiving follow-up services from Fairview field workers in Multnomah County were obtained and examined for names not already enumerated. Through this process, two additional members of the cohort were located. The entire population consisted of 87 individuals, rather than the 
300 initially predicted. It was, therefore decided to select a proportionately smaller random sample than the originally proposed 30 .

A simple random sample was drawn by the method of numbering each individual in the population, putting correspondingly numbered slips of paper in a bowl, and drawing slips one at a time, replacing the slips before the next draw. In this manner, a sample of 18 individuals was drawn, as well as an alternate list of six additional individuals who could be used to replace any member of the sample who was not available for interviews.

The next step consisted of contacting the various mental retardation professionals in Multnomah County in order to obtain current addresses for each member of the sample and for each alternate. We were able to obtain addresses for 14 members of the sample and for four of the alternates. These 18 individuals comprise the cohort. Actual place of residence or consent to be interviewed could not be obtained from six members of the cohort. Thus, the total sample consisted of 12 individuals, each of whom was interviewed at least once.

Anticipated Problems

Based on the readings and consultations undertaken prior to initiating the study, it was predicted that there could be a number of difficulties in conducting a study of 
a mentally retarded adult population. It was anticipated that problems would fall into two broad categories: making and maintaining contact with the individual; and obtaining information and data from the individuals which would honestly reflect their perceived experiences and feelings, rather than responses which were offered to 'pass,' or merely to please the interviewers:

The interviewers were aware of the sensitive issue of being labeled 'mentally retarded.' It was imagined that approaching individuals, explaining the purpose and reason for being there as that of studying retarded citizens would create a distance and defensiveness which would deter the likelihood of getting open, genuine responses. Since the population had resided in Fairview within the last five years, it was additionally supposed that the individuals might be fearful and/or suspicious that they were being checked up on to determine if he or she should be returned to Fairview, despite any verbal reassurances which might be made. Thus, if this were a fear held by individuals, they might feel forced to consent to interviews in order to make a positive impression on a representative of the institution which for many years had controlled and influenced their lives.

The researchers realized that there might be a difficulty in conveying to the retardate that he had a free choice to participate in the interviews. The need to convey 
the freedom of choice was important to create a climate for easy discussion and exchange of personal information, as well as to insure the safeguarding of the individual rights of each subject.

Not only was it imagined that there would be doubts, hesitations and possible defensiveness on the part of the retarded citizen towards strangers entering their 'turf,' but also it was anticipated that those surrounding and working with retarded persons would feel defensive for and protective of the retarded person. Edgerton calls those living near and working with the retarded "benevolent conspirators."(20) These are people like home providers, group home parents, guardians, parents, and caseworkers. The researcher expected that these people might tend to shelter and protect the retardate from inquiries and interactions with strangers who wanted to explore their lives.

Once a successful entry and introduction to the retarded person was made, it was expected that inquiries and questions might be viewed as a test to be passed or failed. The retarded person who has been institutionalized and subsequently released often has experienced a string of situations which convey that he is different, inferior, or unable to do things as normals do them. The interviewers realized that their presence and their inquities might help to create the anxiety that, here again, was a situation which would show the retardate to be incompetent. To create 
yet another experience which would expose the retarded person's lack of performance was not desired. The researchers realized the need to conduct the interviews and conversations in a manner which would avoid forcing the retardate to merely respond 'yes' or 'no' to activities, behaviors, feelings, or abilities.

\section{Implementation}

After obtaining the addresses of the sample population, it was discovered that many of the potential respondents had moved. Often many hours of leg work and multiple contacts were required before locating a current residence. Some of the addresses provided proved to be inaccurate, some did not even exist.

Another difficulty sometimes arose after the initial interview with a respondent. When the researcher would make arrangements for the second or third interview and arrive to conduct it, the respondents sometimes were not at home. This usually meant that several attempts and visits had to be made to arrange for the next interview. Even though the voluntary nature of participation in the study was thoroughly explained, and in fact, repeated during each interview, there was often some difficulty in obtaining a specific 'yes' or 'no' to a request for another interview. The interviewers often encountered, upon arrival for an interview, a respondent who did not 
wish to do the formal interview, but did want a receptive ear for listening, or relating various phys ical ailments or current problems. At times this would lead into the actual interview. Often it would not, and another time would have to be scheduled.

The difficulties encountered with initial contact, entrance, and subsequent interviewing fell between the reported experiences of the Henshel and Edgerton studies. Edgerton reported no trouble locating and conducting interviews with his retarded adult population. (21) Henshel reported that her interviewers encountered immense problems and prolonged delays in finding and completing the interviews. (22)

Another problem which was encountered and which has implication for the analysis and results involved the respondents' willingness to reply to some of the question area. As the interviews progressed from first to third, some of the respondents chose not to comment on certain questions. For some questions only six of 12 respondents provided replies which could appear as data. Thus, on some tables in certain question areas the replies represent a smaller portion of the sample population. 


\section{RESULTS}

Due to the open-ended nature of much of the interviews, a considerable amount of material was generated on each respondent. This section of the report, therefore, consists of three sub-sections. A checklist of certain "hard data" was utilized to make the analysis more manageable. The first subsection is a reporting of the hard data which was to be obtained for all respondents, and which was gathered by collapsing the interviewee's answers into categories condensed from the interview guide. The second subsection reports data pertinent to dependent versus independent behavior and lifestyle. The third subsection presents three composite viewpoints of a dependent, a semiindependent, and an independent retarded adult in the community.

In each of these sketches, names have been changed and a composite of behaviors assembled to protect the privacy of all participants in this study. It should be noted that each of these descriptions was written by a different member of the research team, and thus varies stylistically. This was a purposeful strategy for this subsection of the data which, by its very nature, is highly subjective. The authors wished to maintain the individual perspective each researcher had in reporting 
on his experience with the retarded person described.

Demographic Characteristics of the Cohort

Demographic characteristics of the cohort (age, length of institutional stay, length of residence in the community, and AAMD level) are presented in Table II.

TABLE II

CHARACTERISTICS OF THE COHORT

\begin{tabular}{|c|c|c|c|}
\hline & $\underbrace{\text { Male }}_{\mathrm{N}=7}$ & $\begin{array}{c}\text { Female } \\
\mathrm{N}=11\end{array}$ & $\begin{array}{c}\text { Tota1 } \\
\mathrm{N}=18\end{array}$ \\
\hline Age (range) & $19-31$ & $18-38$ & $18-38$ \\
\hline Age (mean) & 24.9 & 26.3 & 25.7 \\
\hline
\end{tabular}

Length of Institutional Stay (range) $2.00-16.00 \quad 2.50-25.00 \quad 2.00-25.00$

Length of Institutional Stay (mean) $8.50 \quad 9.78$ 9.30

Length of Time in Community (range) $1.50-5.25 \quad .75-6.25 \quad .75-6.25$

Length of Time in Community (mean) 3.00 2.80 2.88

AAMD Leve1 I (Borderline) $\mathrm{N}=2$ $\mathrm{N}=1$ $\mathrm{N}=3$

AAMD Leve1 II (Mild) $\mathrm{N}=4$ $\mathrm{N}=8$ $\mathrm{N}=12$

AAMD Leve1 Undetermined $\mathrm{N}=1$ $\mathrm{N}=2$ $\mathrm{N}=3$

Demographic Characteristics of the Sample

Demographic characteristics of the sample are pre-. sented in Table III. 
TABLE III

CHARACTERISTICS OF THE SAMPLE

\begin{tabular}{lccc} 
& $\begin{array}{r}\text { Male } \\
\mathrm{N}=5\end{array}$ & $\begin{array}{r}\text { Female } \\
\mathrm{N}=7\end{array}$ & $\begin{array}{r}\text { Total } \\
\mathrm{N}=12\end{array}$ \\
\hline Age (range) & $19-31$ & $18-38$ & $18-38$ \\
\hline Age (mean) & 24.0 & 26.7 & 25.6 \\
\hline
\end{tabular}

Length of Institutional

\begin{tabular}{llll} 
Stay (range) & $3.0-12.0$ & $2.5-25.0$ & $2.5-25.0$ \\
\hline
\end{tabular}

Length of Institutional

Stay (mean)

8.25

9.82

9.25

Length of Time in Community (range)

$1.50-5.25 \quad .75-6.25$

$.75-6.25$

Length of Time in

\begin{tabular}{lccc} 
Community (mean) & 3.19 & 3.18 & 3.18 \\
\hline AAMD Leve1 I (Borderline) & $\mathrm{N}=2$ & $\mathrm{~N}=0$ & $\mathrm{~N}=2$ \\
\hline AAMD Level II (Mild) & $\mathrm{N}=2$ & $\mathrm{~N}=6$ & $\mathrm{~N}=8$ \\
\hline AAMD Level undetermined & $\mathrm{N}=1$ & $\mathrm{~N}=1$ & $\mathrm{~N}=2$ \\
\hline
\end{tabular}

Means of age, length of institutional stay, length of residence in the community, and distribution of AAMD levels are similar for both the cohort and the sample, indicating that those individuals successfully contacted and interviewed are representative of the cohort.

The mean age of the sample was 25.6 years, with the mean age of men 24.0 and the mean age of women 26.7. The mean length of institutional stay was 9.25 years, with the mean for men 8.25 years and that for the women 9.82 years. There was a very broad range of institutional stay - from 
2.5 years to 25.0 years - and it should be noted that the 25-year institutionalization of one woman has inflated the mean. Had she not been included in the sample, the mean length of institutional stay for the sample would have been 6.98 years rather than 9.25 years, and the mean for women would have been 6.25 years (less than that for the men) rather than 9.82 years (more than that for the men). The mean length of time in the community was 3.18 years, with the mean for men 3.19 years and for women 3.18 years.

It was not possible to determine the specific AAMD level of two members of the sample; i.e., whether they were Level I or Level II. of the remaining ten members, two were Level I and eight were Level II.

One person was black, all others were white. Four individuals were married, eight were single. Six lived in their own apartments, either alone or with a spouse; three lived in group homes; one in a foster home; and two with their families. Data pertaining to marital status and living arrangements are presented in Table IV.

TABLE IV.

LIVING ARRANGEMENTS OF THE SAMPLE

\begin{tabular}{lccc} 
& $\begin{array}{r}\text { Married } \\
\mathrm{N}=4\end{array}$ & $\begin{array}{c}\text { Single } \\
\mathrm{N}=8\end{array}$ & $\begin{array}{c}\text { Total } \\
\mathrm{N}=12\end{array}$ \\
\hline Apartment & 3 & 3 & 6 \\
Group Home & 1 & 2 & 3 \\
Foster Home & 0 & 1 & 1 \\
Family & 0 & 2 & 2
\end{tabular}


Work

Ten of $12(83 \%)$ of the sample were employed at the time of interview. Of the two who were unemployed, one respondent had recently left a work setting, and the other had never been employed as she was still in school. See Table V.*

TABLE V

CURRENT EMPLOYMENT STATUS

\begin{tabular}{lccc} 
& $\begin{array}{c}\text { Male } \\
\mathrm{N}=5\end{array}$ & $\begin{array}{r}\text { Female } \\
\mathrm{N}=7\end{array}$ & $\begin{array}{r}\text { Total } \\
\mathrm{N}=12\end{array}$ \\
\hline Currently Employed & 5 & 5 & 10 \\
Currently Unemployed & 0 & 1 & 1 \\
Never Been Employed & 0 & 1 & 1 \\
\hline
\end{tabular}

Four ( $40 \%)$ of the employed respondents had held their current job for over two years, four ( $40 \%$ ) had been employed on the current job for six to 12 months, with the remaining two $(20 \%)$ having been employed from three to six months on their current job. See Table VI.

* Although, because of the small N's involved, data are not presented in the body of this report according to sex of respondent, stratification by sex has been included in several of the tables for the benefit of readers who may be interested in this type of comparison. 
TABLE VI

LENGTH OF TIME ON CURRENT JOB

\begin{tabular}{lccc} 
& $\begin{array}{c}\text { Male } \\
\mathrm{N}=5\end{array}$ & $\begin{array}{r}\text { Female } \\
\mathrm{N}=5\end{array}$ & $\begin{array}{r}\text { Total } \\
\mathrm{N}=10\end{array}$ \\
\hline 1-3 months & - & - & - \\
$3-6$ months & 1 & 1 & 2 \\
6-12 months & 1 & 3 & 4 \\
12-24 months & - & - & - \\
over 24 months & 3 & 1 & 4 \\
\hline
\end{tabular}

When asked if they enjoyed their current job, nine of the ten (90\%) responded in the affirmative with only one $(10 \%)$ responding negatively.

Only one of the respondents had never held a work position since release from Fairview Training School. Three of the 12 respondents (25\%) had held one job. Five respondents $(41.6 \%)$ had held two jobs and two $(16.6 \%)$ had held six jobs. Thus, a total of 25 jobs had been held by all respondents. This yields a mean of 2.1 jobs per respondent since release from Fairview.

Respondents were asked "How would you find a new job?" Interviewers assessed responses in terms of independence vs. dependence. Three of the 12 respondents (25\%) would seek a job independently; i.e., without relying on the assistance of another person. Three (25\%) were assessed as semj-independent; they would, on their own initiative, seek out a vocational counselor and request assistance in finding a new job. Six persons (50\%) were assessed as 
dependent because they would not make efforts to find a new job unless another person suggested an idea to them and located the job for them. These figures are based on how the respondents themselves reported they would attempt to get a new job. See Table VII.

TABLE VII

HOW TO FIND A NEW JOB

\begin{tabular}{lccc} 
& $\begin{array}{c}\text { Male } \\
\mathrm{N}=5\end{array}$ & $\begin{array}{r}\text { Female } \\
\mathrm{N}=7\end{array}$ & $\begin{array}{c}\text { Total } \\
\mathrm{N}=12\end{array}$ \\
\hline Independently & 3 & 0 & 3 \\
Semi-Independent1y & 0 & 3 & 3 \\
Dependent1y & 2 & 4 & 6 \\
\hline
\end{tabular}

Respondents were asked a number of questions regarding behavior at their jobs. Responses of the one person who had recently left her job are included so that $N=11$ for this section of the data.

Respondents were asked about their lunch eating patterns. Ten of the 11 (91\%) ate lunch with others at their place of employment. One person ( $9 \%$ ) ate lunch alone. This person would leave his place of employment and eat at his apartment, which was located near his job.

When questioned about what they would do if they had a problem with another worker, one respondent could not imagine this occurring. Of the remaining ten respondents, seven $(70 \%)$ would talk with either the worker or the super- 
visor to solve the problem, while three persons (30\%) would not talk about the problem.

When asked, "If you got the flu and had to stay home from work, what would you do about your job?," nine persons $(81.8 \%)$ stated that they would notify their employer themselves. This was assessed as independent functioning. One person (9\%) would rely on others to notify the employer semi-independent functioning. One person (9\%) would take no specific action - dependent functioning. See Table VIII.

TABLE VIII

RESPONSE TO ILLNESS ON JOB

\begin{tabular}{lccc} 
& $\begin{array}{c}\text { Male } \\
\mathrm{N}=5\end{array}$ & $\begin{array}{r}\text { Female } \\
\mathrm{N}=6\end{array}$ & $\begin{array}{c}\text { Total } \\
\mathrm{N}=11\end{array}$ \\
\hline Independent & 4 & 5 & 9 \\
Semi-independent & 0 & 1 & 1 \\
Dependent & 1 & 0 & 1 \\
\hline
\end{tabular}

The last question regarding the management of the respondents' work-related life concerned how they handled their paychecks or reimbursement for services. For this question area, $N=10$. Five of the ten (50\%) handled their paychecks independently; two persons (20\%) handled their checks semi-independently (with some assistance from other persons), and three people (30\%) were totally dependent on others to handle money for them. See Table IX. 
TABLE IX HANDLING OF PAYCHECK

\begin{tabular}{lccc} 
& $\begin{array}{c}\text { Male } \\
\mathrm{N}=5\end{array}$ & $\begin{array}{r}\text { Female } \\
\mathrm{N}=6\end{array}$ & $\begin{array}{r}\text { Total } \\
\mathrm{N}=11\end{array}$ \\
\hline Independent1y & 3 & 2 & 5 \\
Semi-independently & 1 & 1 & 3 \\
Dependently & 1 & 2 & 2 \\
\hline
\end{tabular}

Respondents were asked to rank order the following attributes of a worker: (a) works fast, (b) is on time for work, (c) smiles on the job, (d) asks questions, and (e) follows instructions. The one notable finding was that ten of the 12 respondents $(84 \%)$ considered punctuality to be the most important attribute of a good worker. There was no pattern of significance for the other attributes as Table $\mathrm{X}$ indicates.

TABLE $X$

RANK ORDERING OF WORKER ATTRIBUTES $(\mathrm{N}=12)$ Attributes

\begin{tabular}{lccccc} 
Rank & On time & Smile & Instruct. & Quest. & Work fast \\
1st & 10 & 2 & 0 & 0 & 0 \\
2nd & 1 & 2 & 2 & 1 & 4 \\
3rd & 0 & 2 & 4 & 2 & 1 \\
4th & 0 & 1 & 1 & 4 & 4 \\
5th & 1 & 3 & 3 & 2 & 1 \\
\hline
\end{tabular}


Avocation

Ten members of the sample were interviewed regarding their social and leisure activities.

Three of the ten $(30 \%)$ reported having hobbies.

Seven persons ( $70 \%$ ) did not have any kind of hobby.

Six persons $(60 \%)$ reported that they left their homes in the evening to seek entertainment, recreation, or association with other people. Four persons (40\%) did not go out in the evenings.

When asked about specific types of out-of-home activities, three respondents (30\%) reported going to taverns or cafe-type places, three respondents (30\%) reported attending church services or church-related meetings or activities, and one respondent (10\%) reported being a participating member in a formally-organized club. This respondent was, however, planning to terminate his association with the club as he disliked the fact that all members were mentally retarded.

In contrast to the above, seven persons (70\%) stated specifically that they never went to taverns or cafes, seven $(70 \%)$ reported that they never attended church functions, and nine (90\%) belonged to no formal clubs.

Respondents reported contact with their neighbors in the following frequency: four persons (40\%) indicated that they spoke with neighbors at least twice weekly while five. persons $(50 \%)$ reported speaking to neighbors only once a 
month. One respondent (10\%) reported that she never saw or sought verbal contact with her neighbors. See Table XI.

TABLE XI

CONTACT WITH NEIGHBORS

\begin{tabular}{lccc} 
& Male & Female & Tota1 \\
& $\mathrm{N}=3$ & $\mathrm{~N}=7$ & $\mathrm{~N}=10$ \\
\hline Never & 0 & 1 & 1 \\
Seldom & 2 & 3 & 5 \\
Often & 0 & 0 & 0 \\
Very often & 1 & 3 & 4 \\
\hline
\end{tabular}

In regard to actively seeking out further contact with a newly-met person, three respondents (30\%) indicated that they would ask for an address or phone number or go visit the person or specifically arrange another meeting. Two respondents $(20 \%)$ indicated that they would do nothing to seek or assure another meeting. And five respondents $(50 \%)$ felt that they had never been confronted with this type of situation and had no idea how they would handle it.

\section{Interpersonal Relationships}

When respondents were asked how often they saw their families, all reported having at least some contact. One person $(10 \%)$ had contact less than once a month; three persons $(30 \%)$ had contact at least once a month; four persons $(40 \%)$ had contact at least once a week; and two persons 
(20\%) lived with their families. See Table XII.

TABLE XII

\section{FAMILY VISITATION}

\begin{tabular}{lccc} 
& $\begin{array}{c}\text { Male } \\
\mathrm{N}=4\end{array}$ & $\begin{array}{r}\text { Female } \\
\mathrm{N}=6\end{array}$ & $\begin{array}{r}\text { Total } \\
\mathrm{N}=10\end{array}$ \\
\hline Never & 0 & 0 & 0 \\
Less than once a month & 0 & 1 & 1 \\
Once a month & 2 & 1 & 3 \\
Once a week & 1 & 3 & 4 \\
Lives with family & 1 & 1 & 2 \\
\hline
\end{tabular}

Five out of nine respondents $(56 \%)$ said that they had a special friend, while four of the nine (44\%) did not have a special friend.

Four members of the total sample were married. Seven of the remaining eight responded to questions about malefemale relationships. Of these, three persons (43\%) reported having a boyfriend or girlfriend, while four persons (57\%) did not have such a relationship:

Seventy-one percent of the respondents wanted to get married eventually, while 29 percent did not ever want to marry.

Eight respondents were interviewed regarding their desire to have children. Fifty percent did want to have children, while 50 percent did not. The desire to have children does not reflect the ability to have children; some of those who reported a desire for children had been 
sterilized. Although respondents were not asked whether they had been sterilized, six of the 12 sample members (five women and one man) volunteered the information that they had undergone this procedure.

Seven people discussed their knowledge of birth control. It was felt that three persons (43\%) had a functional knowledge of at least some reliable method of birth control; i.e., could make use of a method if they chose to do so. The remaining four persons (57\%) had heard of birth control but it was judged that their knowledge was not adequate to enable them to reliably use any method.

Six people were asked how they would respond to a friend who thought that he had a venereal disease and wondered what to do about it. Three of the respondents (50\%) knew that the friend should see a doctor. Two persons $(33 \%)$ had heard of VD but did not know what the friend should do. And one person (17\%) had never heard of VD.

\section{Dependence/Independence}

One of the goals of this study was to assess the relative independence in functioning of members of the sample, in terms of a five-category scale ranging from Very Dependent to Very Independent. This assessment was made in two ways. The first method involved assigning, on the basis of an overall subjective sense of the individual's functioning, each individual to one of the five 
categories .

The second method involved assessing the individual's responses to six particular questions which, it was felt, specifically measured independence of functioning, and assigning a weighted value to the individual's answer. The six questions were (a) how the person would find a new job, (b) how he would handle illness in regard to employmen, (c) how he handled his money (if employed), (d) the kind of social/avocational activities in which he participated, (e) how he would follow up on a social contact, and (f) a composite view of respondents' self-awareness based on their knowledge of birth control and venereal disease. Responses were assigned a score of 1.0 if they appeared to represent dependent functioning, 2.0 if they represented semi-independent functioning, and 3.0 if they represented independent functioning.

After the individual's responses to each of these questions was scored, an average was obtained by dividing the total score by the number of questions which had been scored.

When the individuals' average scores were compared with the original subjective assessment of overall func-

* As Henshel notes: "We attempted to assess the individuals as they would be assessed by 'normals,' by anyone with whom they might come in contact. Cues which the average person would probably use in making a similar judgement were therefore utilized. Granted these assessments were not charitable - nor is life."(23) 
tioning (see Table XIII), it was found that there was virtually complete correspondence between the two measures of independent functioning. That is, individuals subjectively assessed as Very Independent had higher average scores than those assessed as Largely Independent; those assessed as Largely Independent had higher average scores than those assessed as Semi-Independent, etc.

TABLE XIII

ASSESSMENT OF DEPENDENT TO INDEPENDENT FUNCTIONING III

$\begin{array}{ccccc}\text { I } & \text { II } & \text { Semi } & \text { IV } & \text { V } \\ \text { Very } & \text { Largely } & \text { inde- } & \text { Largely } & \text { Very }\end{array}$
Dependent Dependent pendant Independent Independent

\begin{tabular}{lccccc}
$\begin{array}{c}\text { Number of } \\
\text { Individuals }\end{array}$ & 1 & 1 & 3 & 3 & 4 \\
\hline $\begin{array}{l}\text { Individual's } \\
\text { Scores }\end{array}$ & 1.0 & 1.75 & $\begin{array}{l}1.6 \\
1.8\end{array}$ & $\begin{array}{l}2.0 \\
2.2\end{array}$ & $\begin{array}{l}2.6 \\
2.5\end{array}$ \\
& & & 2.1 & 2.5 & 3.0 \\
\hline $\begin{array}{l}\text { Average } \\
\quad \text { Score }\end{array}$ & 1.0 & 1.75 & 1.9 & 2.2 & 2.8 \\
\hline
\end{tabular}

When an average score was computed for each category, based on the scores of all individuals assigned to that category, it was found that there was a progression from lower score to higher score which corresponded to the progression from Very Dependent to Very Independent. The Very Dependent category had an average score of 1.0, the Largely Dependent category had an average score of 1.7 , the SemiIndependent category had an average score of 2.2, and the Very Independent category had an average score of 2.8. 
The one anomaly which appears in the table, a respondent with a numerical score of 1.6 was assessed as Semi-Independent whereas the respondent who was assessed as Largely Dependent had a numerical score of 1.7 , is the result of the original subjective assignment of individuals to categories. In this case the Semi-Independent respondent was assessed as having an overall more independent lifestyle than the Largely Dependent respondent.

Table XIV presents a comparison of the assessed independence/dependence of the sample to the length of institutional stay and to the length of community residence.

TABLE XIV

DURATION OF COMMUNITY AND INSTITUTIONAL RESIDENCE RELATED TO INDEPENDENT FUNCTIONING

\begin{tabular}{|c|c|c|c|c|c|}
\hline $\begin{array}{l}\text { Leve1 on } \\
\text { Which } \\
\text { Functioning }\end{array}$ & $\begin{array}{c}I \\
\text { Very } \\
\text { Dependent } \\
\mathrm{N}=1\end{array}$ & $\begin{array}{c}\text { II } \\
\text { Largely } \\
\text { Dependent } \\
\mathrm{N}=1 \\
\end{array}$ & $\begin{array}{c}\text { III } \\
\text { Semi- } \\
\text { Independent } \\
\mathrm{N}=3 \\
\end{array}$ & $\begin{array}{c}\text { IV } \\
\text { Largely } \\
\text { Ind ependent } \\
\mathrm{N}=3 \\
\end{array}$ & $\begin{array}{c}\mathrm{V} \\
\text { Very } \\
\text { Independent } \\
\mathrm{N}=4 \\
\end{array}$ \\
\hline $\begin{array}{l}\text { Average } \\
\text { Leng th of } \\
\text { Time in } \\
\text { Community }\end{array}$ & 75 mos. & 60 mos. & 14 mos. & 18 mos. & 50 mos. \\
\hline $\begin{array}{l}\text { Average } \\
\text { Length of } \\
\text { Time in } \\
\text { Institution }\end{array}$ & 30 mos. & 300 mos. & 102 mos. & 72 mos. & 126 mos. \\
\hline
\end{tabular}

Data for the first two categories are not considered 
to be significant or representative because of the small N's. Persons in the Semi-Independent category had been at Fairview for an average of 102 months and in the community an average of 14 months. Those in the Largely Independent category had been at Fairview for an average of 72 months and the community for an average of 18 months. Those in the Very Independent category had been at Fairview for an average of 126 months and in the community for an average of 50 months. It should be noted that one of the Very Independent respondents had been institutionalized in a neighboring state immediately prior to his admission at Fairview; his total institutional life, rather than just time at Fairview, was used to determine the category average. There does not appear to be any definite relationship between length of institutional stay and level of independent functioning. There does, however, appear to be a positive relationship between length of community residence and level of functioning; that is, respondents who had lived in the community longer tended to be more independent in their functioning.

Assessed independence/dependence was also compared with the living arrangements of sample members. 
TABLE XV

ASSESSED INDEPENDENCE/DEPENDENCE COMPARED

TO LIVING SITUATION

\begin{tabular}{|c|c|c|c|c|c|}
\hline & $\begin{array}{c}I \\
\text { Very } \\
\text { Dependent } \\
N=1\end{array}$ & $\begin{array}{c}\mathrm{II} \\
\text { Largely } \\
\text { Dependent } \\
\mathrm{N}=1\end{array}$ & $\begin{array}{c}\text { III } \\
\text { Semi- } \\
\text { Ind epend ent } \\
\mathrm{N}=3\end{array}$ & $\begin{array}{c}\text { IV } \\
\text { Largely } \\
\text { Independent } \\
\mathrm{N}=3\end{array}$ & 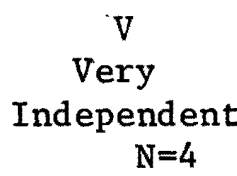 \\
\hline $\begin{array}{l}\text { Independ- } \\
\text { ent } \\
\text { Living }\end{array}$ & --- & $-\cdots$ & 1 & 1 & 4 \\
\hline $\begin{array}{l}\text { Group } \\
\text { Home }\end{array}$ & --- & 1 & 1 & 1 & --- \\
\hline $\begin{array}{c}\text { Foster or } \\
\text { Family } \\
\text { Home }\end{array}$ & 1 & --- & 1 & 1 & --- \\
\hline Totals & 1 & 1 & 3 & 3 & 4 \\
\hline
\end{tabular}

As Table XV illustrates, there was a rather even distribution of living arrangements between group homes or family/foster family situations for all but the most independent individuals. All four individuals designated as Very Independent lived in an independent living arrangement, either alone or with a spouse. It should be noted that the living arrangement itself was not one of the criteria upon which the assessment of independent functioning was based.

Three Retardates in the Community: A Composite View.

Mary Ann: A Dependent Respondent

Mary Ann is 18 years old, but could easily be mistaken for 
12 because she is petite and slender with delicate, childlike features. A quick temper which frequently gets her into fights at home and at school contrasts with her demure appearance.

Mary Ann lives with rather elderly foster parents who have cared for her since her release from Fairview six years ago, and with a 15-year-old foster sister who is also mentally retarded. Their home is located in a lower middle-class suburban neighborhood of small ranch houses.

She attends a training center/school for retarded children from which she will graduate this June.

Mary Ann is almost totally dependent on her environment for behavioral cues. Her foster mother wakes her in the morning, tells her what to wear, and reminds her to attend to personal grooming chores. Following breakfast, she is told when it is time to catch the schoolbus, which picks her up in front of the house.

She attends school for approximately six hours during the day, apparently following whatever routine the teachers suggest without much comprehension of an overall schedule. She was unable to describe a typical day at school and had no particular likes or dislikes beyond saying that lunch time is the only good part of the school day. Mary Ann does not like going to school because, as she explained, "there are a couple of retarded kids there." 
When Mary Ann comes home from school, she spends her free time watching TV or, occasionally, working jigsaw puzzles. She could not think of any household chores which she is expected to perform.

Mary Ann was interviewed a week before she was to begin an "apprenticeship" training in a sheltered workshop in conjunction with her school program. It is planned by her school counselors - that she will work there regularly following completion of school. She know that she was going to be spending time away from her school and that she would have to ride a city bus, to and from the place she was going, but displayed no understanding of what kind of place she would be going to, what she would be doing there, or why this change in routine was happening to her. She seemed neither alarmed nor excited about the change, just docile and accepting of the fact that her counselor had told her she would be doing this. She had no idea of how to use the city bus system but seemed to assume that somehow she would get where she had to go.

Mary Ann's mother and sister visit her in the foster home every week; she does not know how these visits are arranged nor how she would take the initiative to cancel a visit or arrange for an extra one.

She occasionally attends dances for retarded citizens 
with a counselor; again, she does not know what group sponsors the dances or when or where they are held but will go along to one if the counselor suggests it. She refers to this counselor as a "sister," understanding that she isn't a real sister, unsure of what the relationship actually is, but expressing the sentiment that this woman is "close as a real sister" to her.

Mary Ann appears to be content with her lifestyle, willing to depend on others to tell her what to do, and when and how to do it. She displayed no resentment about her lack of self-determination nor any initiative to achieve increased control over her own life.

\section{Roberta: A Semi-Independent Respondent}

Morning comes to the rooming hotel, along with the sounds of the early risers. In the small, clean but cluttered room that is their home, George and Roberta Q. are about to begin another day. Roberta is a retarded person; her husband is normal. George is probably awake already; he will allow Roberta to sleep a little longer, then awaken her. For Roberta the day often begins with a cue, a permission from her husband to get up, much like a young child. The day continues as a mixture of dependent and independent behavior.

The hotel where they live is in a run-down part of town. The Q.'s are presently supported by welfare, a1though until recently Roberta supplemented this with 
income from a job which she quit. Most of the other roomers in the hotel are transients. The Q.'s have lived here for approximately six months. Roberta is a friendly, open woman with a garrolous teasing nature. Her husband is older and treats her in a fatherly manner. Roberta takes the dog for a morning walk and goes to the store to buy some milk. The neighbors know her. If anyone should "bother with" her, she has friends to look out for her. Especially one A---, another older man who lives in the same building.

Today is one of the days when George will let Roberta cook, being careful that she doesn't use the oven, but allowing her to fry up some chicken on a burner. Roberta is grateful for the protection and support she gets from her husband, including learning how to cook. For her part, she is a conscientious cleaner and keeps their small world, which is stuffed with pictures and electrical appliances, many of them in disrepair, orderly.

Roberta has no special hobbies, although she used to dance before she was married, and also likes to draw. She is trying to learn how to write words and letters. Her drawings are on the walls and door of the small room.

After an early afternoon dinner, Roberta will visit with her foster family, something she does quite often. She takes the bus herself to spend the day with this large extended family. When she enters her foster mother's home, 
all the nleces and nephews run up to her, wanting to play. She has a special talent with children her husband has observed.

Roberta's foster mother has heard of an employer who needs help and hires mentally retarded persons. Roberta is interested in the job and together they drive to see the employer. Roberta herself goes into the interview. The position involves sorting and pricing used merchandise. Roberta and her foster mother return home, excited about having a new job. She hopes that things will work out better at this job than at a previous job where her hot temper caused some problems with co-workers. At this job she had some friends to keep her out of trouble. She still maintains contact with one of these friends by phone, but doesn't see her. often.

After supper, Roberta will play with her nieces and nephews and other kin. Tonight she is babysitting for one of her foster sisters, a job she enjoys and does quite often. The evening consists of watching television and playing with her relatives. She will get a ride back to the downtown hotel later in the evening, happy and eager to be with her husband and perhaps a few acquaintances and residents of the hotel before she retires for the day.

I have attempted to portray in this 'day in the life' a semi-independent retarded adult as I observed her and by her report. In many ways her life appears independent, 
i.e., she is married to a normal man, maintains a home, has worked, rides busses, etc. However she herself feels she needs "someone to help if I fall."

Roberta is happy to live her life outside of "Salem," the euphemism for the Fairview Training School. She hopes to be married a long time. She has a rich family life through her foster family and extended relationships. An interesting anecdote, while I was waiting for one meeting with Roberta, I wandered into a local shop to browse and keep warm. The store owner, noticing my taperecorder, asked what I was doing. In very general terms, I explained the nature of our research. She then asked, "You mean you are visiting the lady with the little dog." I did not reply, explaining that I could not reveal the identity of any interviewee. This incident served to indicate more clearly that Roberta lives in a fairly secure world where she is known to be 'different' yet helped and given some amount of protection and support. Roberta can do much. for herself, but also recognizes her need for others. She seems to have little anxiety regarding this need and the ensuing dependency relationships..

Fred: An Independent Respondent Fred Franklin is an example of one of the more independent members of the sample population we interviewed. If you met Fred on the street, in a store, at a bus stop, or walking in a park, and talked with him (which would probably happen because he would strike up a conversation 
with you), you would probably assume you were conversing with a man who was well within the range of "passing" normalcy. Neatly and conservatively dressed, Fred would comfortably chat with you about himself, you, or a topic of mutual interest. He might discuss his past, present, or his hopes for the future. He would ask you questions to clarify or individualize the content of your conversation.

Fred is 31 , lives by himself in a studio apartment which is one of several such units within an old house. Fred works as a kitchen dishwasher in a large. Portland institution. He has worked there regularly for more than two years and earns $\$ 3.26$ per hour. Fred's job is a large source of pride and identity for him. He openly discusses both the skills he has and those he is learning, as well as the mistakes and problems he has encountered. Fred notes that he knows he must pay attention and ask questions about the responsibilities at work he is not clear on. He adds that he must watch himself so he does not talk so much that he cannot complete his duties.

Fred displays his awareness of and coping skills with others when he discusses the special needs of his boss, whom Fred describes as an especially nervous person who cannot stand a lot of loud noises.

Fred independently administers his own finances. With his paycheck he buys his own groceries, pays his 
bills, and purchases items which he uses in his spare time. He explains that only by saving from each paycheck can he afford to buy fishing gear, radios, tape recorders, calculators, and other items he has or wants to have for his own entertainment. Fred explains that he has found certain stores which sell things more cheaply than others. He also realizes that he has a phone bill which frequently includes long distance calls to his parents in another part of the state.

During his non-working hours, Fred selectively spends time alone at home working, cleaning, amusing himself with several hobbies; and visiting places and people in various parts of Portland. He devotes much time to his fishing equipment and to planning fishing outings which he takes on weekends or days off. Fred uses the bus to get to places he decides to go. He has developed a thorough knowledge of the bus system so that he can get himself to all parts of town, as well as into the country to fishing spots. The bus is also used to transport himself south to the town where his parents reside.

Fred explains that he likes to visit his folks on his free weekends "because they are getting older and can use my help around the house and garden and because I enjỏy going fishing with them." Although Fred looks forward to his visits with his folks, it is clear that 
the choice and times for the visits are his to implement. Fred openly discusses his family's history. He describes in detail the times and places he and his family have lived, both together and separately. This awareness of the past does not seem to be a preoccupation but rather a concrete part of his conception of himself. Right along with this is an open reference to his lengthy stay in the Fairview Training School. Fred relates his perception of his handicaps and limitations both past and present. "Sometimes I get excited and get to talking too fast and just run one thing into another, so will you stop me if you hear me doing this?" "There are some things I have some problems with, like understanding some written instructions, so I ask people to help me."

Fred is a "self-cueing" person. He does not wait for things to happen to him. Instead, he selects activities to pursue and seeks interactions with people he knows. Calling another person on the phone, going on the bus to another part of town to a store, a movie, or a dance are regular and self-planned activities. As mentioned earlier, Fred is aware of his limitations. He explains that he knows people both at work and around the neighborhood whom he calls to ask for help when he needs to be taken some place or if, for example, he needs assistance cashing a check. 
Even though Fred actively initiates most of his social and personal activities, he also actively protects himself from situations he considers unsafe. He explains that he has turned down car rides from people he has learned drive too fast. He comments that he does not like to be out alone after dark because it is unsafe.

Fred divides his friends into two categories: people he has known at Fairview or whom he has met in Portland who had been in Fairview, and people he has met at work who help him out or give him suggestions and who he in return tries to help through doing a favor or paying for some gas or some treat.

Fred has a girlfriend he calls up and who calls him up. They go to movies, wrestling matches, or to dances. He met her in Fairview and says they waited 12 years before going with each other because he had other girlfriends at Fairview. Fred says that someday he would like to get married but agrees with his parents that he is not ready yet. "I still have some problems I need to work out and I'1l probably be ready to get married when I'm 35." Fred speaks in practical terms about the changes marriage would bring for him in terms of needing to have a larger place to live and needing to pay twice as much for living expenses. He also says he will wait because of the things he hears about divorces, fights, abandonment, and two-timing. He stresses that none of these things does he want when he gets married. 
Fred's view of what his marriage would be like is one where his wife would not have to work too long herself. She would stay home, would care for their apartment, and would cook except when she was too tired. Then Fred would cook and would also teach her some of the things he has learned from his kitchen work. Fred notes that he would like to adopt some kids since he cannot have any "because I've been sterilized." Fred openly appraises his chances to adopt kids and says raising kids is a big responsibility. He acknowledges the complications involved in adoption and says that it might be difficult for him because he would have to prove he was capable of handiing children.

In my interviews with Fred, I was struck by his openness and willingness to talk about many personal subjects. Fred was eager to express his pride and competencies and he was equally willing to state his needs, weaknesses, and areas of incomplete knowledge. This is best reflected in our conversation concerning birth control and venereal disease. Fred clearly and without embarrassment was able to imagine giving information and advice to a friend, but even more significantly, volunteered to direct his responses to his personal experiences. He noted that through films and talks with health department officials he had learned about "intercourse, reproduction, syphilis, and gonorrhea." His statements about contra- 
ception, intercourse, and the symptoms and ways to contact venereal disease were thorough and consistent. He also explained that he had earlier in his stay in Portland been reluctant to ask questions about VD or sex but had decided that the only way to find out was. to ask. An example given was when he had talked with a landlady about a sexual contact he had and was concerned about.

Fred Franklin is operating independently in the Portland community. His daily routine is one in which he initiates his own interactions with people and activities. He gathers and processes new information from his experiences, compares these with his prior repertoire of experiences, and chooses adaptations or additions to his routines, behaviors and attitudes. 


\section{CONCLUSIONS AND IMPLICATIONS}

A wide range of empirical and subjective information on the sample population was accumulated and presented. With a subjective general sense, the researchers assess the sample population as ably living in, interacting with, and functioning within the Portland community. This is not to say there were no day-to-day problems in general life functioning that were either reported by the respondents or directly observed by the interviewers. However, no respondent reported or appeared to be incapable or unwilling to live in the community. In fact, all respondents related behaviors that suggest they are functioning within the community at personally pleasing levels of behavior. No one reported or appeared unable to live in the community within the subjective standards generally termed "socially acceptable." Nor did any respondent report or demonstrate a need for the supports and structure which Fairview had once provided.

In terms of dependence-independence, the sample was assessed as varying from very dependent to very independent in levels of personal and community functioning. There is a broad range of dependent to independent functioning among the retarded population that has the label "mild to borderline." Although a wide range on this variable 
was reported, a noteworthy trend is observable. The respondents assessed as largely, very, and semi-independent are also the respondents who have lived in the community the greatest length of time. No one assessed at these relatively independent levels has resided in the community for less than three years. The length of stay within the Fairview Training School does not appear to coincide with the assessed levels of independence for the sample. The researchers conclude that independent functioning is likely to be a function of time lived outside of an institutional setting.

Another conclusion concerns the living situation of the respondents and how that relates to independent levels of functioning. Those respondents who lived alone were those assessed as very or highly independent. Those respondents who lived in private family homes or group home settings, : where a more "closed" and structured interactional environment existed, were the respondents who, on the whole, were not as independent. This conclusion coincides with that of the Bjaanes and Butler study where the retarded citizens who lived in the minimally supportive environment of rooming houses were judged to have a better social adjustment to community life than retarded persons who lived in foster homes or other self contained community settings. 24 This finding has implications for the kinds of "community care" settings where the mentally 
retarded adult is being placed in Oregon. If retarded adults are being placed in group home settings; are professionals, thereby, merely creating the opportunity for decentralized, "mini-institutions?" And are they thus creating alternative institutionalienvironments which are less likely to encourage and support the potential for maximum self-sufficiency in an adult retarded population?

No matter what the living situation or assessed level of independent to dependent functioning, the sample population spoke directly about or made reference indirectly to an absence of social contact with normals. Repeatedly the interviewers heard or observed that there were few opportunities for social activities with non-mentally retarded citizens. Most of the sample population had minimal personal contact with normals except in terms of the formal and informal "benevolent conspiracy." The sample had received some contact with normals who functioned to help them out, or to aid them through specific difficulties or crises. This network of aid and assistance is undoubtedly wanted and necessary. In addition, the respondents expressed a desire for social activities with other people who are not retarded and who would not further create, by association, the stigma of "retarded." At the People's First convention in the fall of 1974, the researchers also heard retarded persons saying they had a 
need to be considered and treated as normal people first. During the research interviews this request for purely personal, non-stigmatizing interaction with other people was again expressed. The rationale for supporting and helping to create social and living environments where retarded adults have more control over their lives and can work, live, and socialize with others of similar abilities is based on the idea that retarded persons need to be protected from additional failure experiences. This is one viewpoint which certainly arouses empathy and nuturance from the helping community. We report that the retarded adult is clearly saying he would like the chance to experience and relate to normal people in normal social settings.

\section{Qualifications}

The above conclusions, and indeed the report of the data, as presented in the previous chapter of this study, need to be qualified and considered in light of the small size of the sample. This study was meant to be an exploratory study, due to constraints in time, manpower, and money. This fact, coupled with the difficulty in securing all of the intended interviews, limited the potential actual sample interviewed. The effect of this small sample becomes more acute when dealing with the questions and considerations of interpersonal relations. Compre- 
hensive interviews were completed with only six respondents, as opposed to an original sample pool of 12 . Obviously, further investigations should be conducted on a larger scale. We did, however, ascertain that information can be gathered on highly personal aspects of the lives of mentally retarded adults.

Another question which can be raised is: was the sample representative of the Educably Mentally Retarded in Multnomah County, or only of that population which had been in Fairview Training School and Hospital? Do persons who have been diagnosed EMR, but who have not had careers as residents of an institution, lead lives which are significantly different, especially in terms of dependence/independence, than our small sample lead? This raises the question of whether a previously institutionalized population has perhaps different needs (especially emotionally) than a population which has not been institutionalized. This study does not attempt any comparisons; thus the data should be considered representative only of the ex-institutionalized population.

Another qualification which has been previously noted concerns the use of self-reported data. The researchers were consistently faced with ambiguities and conflicting reports when attempting to assess temporal sequencing of events in the lives of the sample respondents. Weeks, months, and years as abstractions were not 
as clearly conceptualized and understood for many of our respondents as for a normal population. It is possibly necessary to do more verification, where possible, with secondary sources when dealing with temporal issues with this population than the researchers undertook.

A last qualification is highly subjective, but deserves mention. It is extremely easy to become another one of the 'benevolent conspirators' when one enters into the world of the mentally retarded adult. The possibility of interviewer bias, especially in unconsciously shaping the response of the interviewee to a particular question, seems to be a real facter in this type of study. The design did not adequately control for the intrusion of this possible bias; however, this could be done in future studies without difficulty. Certainly, one must allow that differences in interviewer style and skill affected the data generated. These inherent differences and possible biases should be considered when examining the data.

Implications for Further Research

Several implications for future research arise from this descriptive study of a mentally retarded population. As the researchers attempted to assess the level of functioning of the sample, they were aware of the lack of validation of the criteria utilized and hence the sub- 
jective nature of the judgements they made. There is need, through further research, to validate the criteria for independent functioning (or develop new ones) and from this to devise an objective means of assessing the level of functioning of an individual in the community.

Once valid and reliable assessment means are available, they should be utilized to study the factors which promote independent functioning. Such a study would have implications for the design of education/training/ service delivery programs which would facilitate the independent functioning of mentally retarded adults. One possible avenue of such exploration revealed by this study is the apparent relationship between length of community residence and functioning level. Are there aspects of community residence that promote independent functioning?

The researchers conclude that there was great value in letting the retarded speak for themselves about their lives and would encourage future researchers to continue employing this approach. Not only does this type of design follow the principle of normalization; it also is the only reliable method of ascertaining what the retarded perceive themselves to be, to have, and to need. Thus this design avoids the trap of attributing one's own desires to another group when developing programs . 
This study revealed one particular area in which this type of research should be undertaken - a social and recreational needs assessment. The people interviewed had very limited social/recreational outlets, despite the existence of several specific social programs for the retarded in Portland. Apparently the programs that exist do not adequately meet needs. A needs assessment from the point of view of retarded individuals themselves would indicate the manner in which existing programs could be modified or supplemented in order to be more effective in serving the population. 
FOOTNOTES

1. Gozali, Joav; "Citizenship and Voting Behavior of Mildly Adults: A Pilot Study," AJMD, 75(5), 1971, p. 640.

2. Wolfensberger, Wolf; The Principle of Normalization in Human Services, Nat'I Institute on Mental Retardation, Toronto, Ontario, Canada, 1972, p. 28.

3. State of Oregon; Comprehensive Developmental Disabilities Plan, 1972, p. 26 .

4. Tarjan, G., et al; "Natural History of Mental Retardation: Some Aspects of Epidemiology," AJMD, 77(4), 1973, p. 369 .

5. Katz, Elias; The Retarded Adult in the Community, Charles C. Thomas, Springdale, Illinois, 1968, p. 36.

6. Ibid., p. 36 .

7. Henshel, Anne-Marie, The Forgotten Ones: A Sóciological Study of Anglo and Chicano Retardates, University of Texas Press, Austin, Texas, 1972, p. vii.

8. State of Oregon, op. cit., p. 31 .

9. Edgerton, Robert B., The Cloak of Competence, University of Calif. Press, Berkeley, Calif., 1967, p. 99.

10. Katz, Elias, op. cit., p. 75.

11. Ibid., p. 6 .

12. Ibid., p. 7 .

13. Ibid., p. 7 .

14. Mercer, Jane R., Labeling the Mentally Retarded, Univ. of California Press, Berkeley, Calif., 1973, p. 27.

15. Ibid., p. 1 .

16. Edgerton, op. cit., p. 194. 
17. Bjaanes, Arnet, and Butler, Edgar W. "Environmental Variations in Community Care Facilities for Mental1y Retarded Persons," AJMD, 78(4), 1974, p. 431.

18. Selltiz, Claire, et al, Research Methods in Social Relations, Holt, Rinehart and Winston, New York, New York, 1959, p. 236.

19. Henshel, op. cit., p. xi.

20. Edgerton; op. cit., p. 172.

21. Ibid., p. 17.

22. Henshe1, op. cit., pp. 14-16.

23. Ibid., p.

24. Bjaanes and Butler, op. cit., p. 438. 


\section{BIBLIOGRAPHY}

Books

Baumeister, Alfred A. (ed.). Mental Retardation. Chicago: Aldine Publishing Company, 1967.

Cobb, Henry V. The Forecast of Fulfillment: A Review of Research on Predictive Assessment of the Adult Retarded for Social and Vocational Adjustment. New York: CoIumbia University Press, 1972.

de 1a Cruz, Felix F. and La Veck, Gerald D. (ed.) Human Sexuality and the Mentally Retarded. New York: Brunner/ Mazel, Publishers, 1973.

Dybwad, Gunnar. Challenges in Mental Retardation. New York: Columbia University Press, 1964.

Edgerton, Robert B. The Cloak of Competence: Stigma in the Lives of the Mentally Retarded. Berkeley and Los Angeles: University of California Press, 1967.

Henshe1, Anne-Marie. The Forgotten Ones: A Sociological Study of Anglo and Chicano Retardates. Austin: University of Texas Press, 1972.

Katz, Elias. The Retarded Adult at Home: A Guide for Parents. Seattle, Washington: Special Child Publications, 1970.

Katz, Elias. The Retarded Adult in the Community. Springfield, Illinois: Charles C. Thomas, 1968.

Kirman, Brian H. The Mentally Handicapped Child. New York: Taplinger, 1973.

Mercer, Hane R. Labeling the Mentally Retarded. Berkeley: University of California Press, 1967.

Schreiber, Meyer (ed.) Social Work and Mental Retardation. New York: The John Day Company, 1970.

Selltiz, Claire; Jahoda, Marie; Deutsch, Morton; and Cook, Stuart W. Research Methods in Social Relations. New York: Holt, Rinehart and Winston, 1959. 
State of Oregon. Comprehensive Developmental Disabilities Plan. 1972 .

Wolfensberger, Wolf. The Principle of Normalization in Human Services. Toronto, Canada: National Institute on Mental Retardation, 1972.

\section{Journal Articles}

Abe1, Theodora M. "A Study of a Group of Subnormal Girls Successfully Adjusted in Industry and the Community." American Journal of Mental Deficiency, XXXXV, 66-72.

Alker, Leslie N. and Allen, Robert M. "A Realistic Look at Training Needs." Mental Retardation, XII (Feb., 1974), 34.

Baker, Keith. "A Scale of Verbal Accessibility in Mild and Borderline Retarded Adults." Unpublished Masters Practicum, Portland State University School of Social Work, 1972.

Baller, W.R. "A Study of the Present Social Status of A Group of Adults, Who, When They Were in Elementary School, Were Classed as Mentally Deficient." Genetic Psychology Monograph, XVIII (1936), 165-244.

Bass, Medora. "Sex Education for the Handicapped." Family Coordinator, XXIII (1), 27-33.

Bass, M. "Marriage, Parenthood, \& Prevention of Pregnancy." American Journal of Mental Deficiency, LXVIII (1963), 318-333.

Becker, Ralph L. "Vocational Choice: An Inventory Approach." Education and Training of the Mentally Retarded, VIII (Oct., 1973), 128-136.

Bjaanes, Arne T. and Butler, Edgar W. "Environmental Variation in Community Care Facilities for Mental1y Retarded Persons." American Journal of Mental Deficiency, LXXVIII (1974), 429-439.

Boroskin, Alan; Butkus, Richard; and Souders, Carol. "Profiling Adaptive Behavior: A Computerizing Approach." Neuropsychiatric Institute- Pacific State Hospital Research Group. Pomona, California: IDB Publication Series No. 4, Nov., 1973. 
Brolin, Donn. "Value of Rehabilitation Services and Correlates of Vocational Success with the Mental1y Retarded." American Journal of Mental Deficiency, LXXVI (1972), 644-651:

Brown, Ann L.; Campione, Joseph C.; Bray, Norman W.; Wilcox, Barbara L. "Keeping Track of Changing Variables: Effects of Rehearsal Training and Rehearsal Prevention in Normal and Retarded Adolescents." Journal of Experimental Psychology, CI (Nov., 1973), 123-131.

Campbeill, Alison C. "Aspects of Personal Independence of Mentally Subnormal and Severely Subnormal Adults in Hospitals and in Local Authority Hostels." International Journal of Social Psychiatry, XVII (Winter, 1971), 305-310.

Carr, C.L. and McLaughlin, J.A. "Self Concepts of Mentally Retarded Adults in an Adult Education Class." Mental Retardation, IX (Dec., 1973), 57-59.

Charles, D.C. "Adult Adjustment of Some Deficient American Children." American Journal of Mental Deficiency, LXII (1957), 302-304.

Charles, Don C. "Ability and Accomplishment of Persons Earlier Judged Mentally Defective" Genetic Psychology Monographs, XLVII (1953), 3-71.

Clark, E.T. "Sex Role Preference in Mentally Retarded Females." American Journal of Mental Deficiency, LXVIII (1963), 433-439.

Cobb, Henry V. "The Attitude of the Retarded Person Towards Himself." Social Work and Mental Retardation. Edited by Meyer Schreiber. New York: The John Day Company, 1970.

Cohen, Julius and Rusalem, Herbert. "Occupational Values of Retarded Students." American Journal of Mental Deficiency, LXIX (1964), 54-61.

Collins, Burger and Doherty. "Self-Concept of EMR and Non Retarded Adolescents." American Journal of Mental Deficiency, LXXV (1970), 285-289.

Cowan, L. and Godlman, M. "Selection of the Mentally Deficient for Vocational Training and the Effect of this Training on Vocational Success." Journal of Consulting Psychology, XXIII (1959), 78-84. 
Daniels, Lloyd K. "An Experimental Edition of a Rating Scale of Vocational Adjustment for the Mentally Retarded." Training School Bulletin, LXIX (Aug., 1972), 92-98.

Dinger, Jack C. "Post-School Adjustment of Former Educable Retarded Pupils." Exceptional Children, XXVII (March, 1961), 353-360.

Doleys, Janice M. and Ernest, J. "Need for Social Approval and Sheltered Workshop Performance." Rehabilitation Counseling Bulletin, XIV (June, 1971), 213-217.

Domino, George and McGarty, Maureen. "Personal and Work Adjustment of Young Retarded Women." American Journal of Mental Deficiency, LXXVII (Nov., 1972), $314-321$.

Edgerton, Robert B. and Sabagh, George. "From Mortification to Aggrandizement: Changing Self Concepts in the Careers of the Mentally Retarded." Psychiatry, XXV (1962), 263-272.

Fairbanks, Ruth E. "The Subnormal Child - Seventeen Years After." Mental Hygiene, XVII (April, 1933), 177-208.

Floor, Lucretia; Baxter, Donald; and Rosen, Marvin. "Subject Loss in a Follow Up Study." Mental Retardation, X (June, 1972), 3-5.

Gordon, So1. "Okay, Let's Te11: It Like It Is Instead of Just Making it Look Good." Journal of Special Education, V (Winter, 1971), 379-381.

Gorlow, L.; Butlèr; and Guthrie. "Correlates of SelfAttitudes of Retardates." American Journal of Mental Deficiency, LXVI (1963), 549-555.

Goroff, Norman. "Research and Community Placement Án Exploratory Approach." Mental Retardation, $\mathrm{V}(1967), 17-19$.

Gozali, Joav. "Citizenship and Voting Behavior of Mildly Retarded Adults." American Journal of Mental Deficiency, LXXV. (1971), 640-641.

Guthrie; Butler; Gorlow, and White. "Non-verbal Expression of Self-Attitudes of Retardates." American Journal of Mental Deficiency, LXIX (1964), 42-49. 
Guthrie, G.M. "Personality Differences Between Institutionalized and Non-Institutionalized Retardates." American Journal of Mental Deficiency, LXVII $(1963), 543-548$.

Hal1, Judy E.; Morris, Helen I. and Barker, Harry R. "Sexual Knowledge and Attitudes of Mentally Retarded Adolescents." American Journal of Mental Deficiency, LXXVII (May, 1973), 706-709.

Hall, Sylvia M. and Talkington, Larry W. "The Redwood Project." Training School Bulletin, LXIX (May, 1972), $10-12$.

Huddle, Donald D. "Work Performance of Trainable Adults as Influenced By Competition, Cooperation, and Monetary Reward.". American Journal of Mental Deficiency, LXXII (1967), 198-211.

Jackson, R.N. "Prognostic Significance of Performance - Verbal Ability Patterns in Predicting Employment Adjustment of EMR Adolescents." American Journal of Mental Deficiency, LXXVIII (Nov., 1973), $331-333$.

Jackson, S. and Butler, A.J. "Prediction of Successful Community Placement of Institutionalized Retardates." American Journal of Mental Deficiency, LXVIII (1963), 211-217.

Joint Committee of the Sex-Information and Education Council of the U.S. and the American Association for Health, Physical Education, and Recreation. A Resource Guide in Sex Education for the MentalIy Retarded. Klappholz, Lowell (eds.), Washington D.C., American Association for Health, P.E. and Recreation, 1971.

Kraus, J. "Supervised Living in the Community and Residential And Employment Stability of Retarded Male Juveniles." American Journal of Mental Deficiency, LXXVII (Nov., 1972), 283-290.

Laing, Alice. "Group Structures in Retarded Adolescents." American Journal of Mental Deficiency, IXXVI (1972), $481-490$.

Lent, James R. et. al. "Direction Following of Retarded and Non Retarded Adolescents." American Journal of Mental Deficiency, LXXVIII (Nov., 1973), 316322 . 
McFa11, T.M. "Post School Adjustment: A Survey of 50 Former Students of Classes for the Educable Mentally Retarded." Exceptional Children, XXXII (1966), 633-634.

Meyerowitz, Joseph H. "Sex and the Mentally Retarded." Medical Aspects of Human Sexuality, V (Nov., 1971), 94-118.

Miller, E.L. "Ability and Social Adjustment at Midlife of Persons Earlier Judged Mentally Deficient." Genetic Psychology Monographs, LXXII (1965), 139-198.

Morganstern, Murry. "Sexuality, Marriage, and Parenthood Among the Retarded." Journal of Clinical Child Psychology, II (Winter, 1973), 27-28.

Muench, George A. "A Followup of Mental Defectives After 18 Years." Journal of Abnormal and Social Psychology, XXXIX (1944), 407-418.

Nelson, C.C. "Developing a Positive Self-Concept in the Mentally Retarded." Mental Retardation, I (1963), 28-31.

O'Connor, Gail and Sitkei, E. George. "The Study of a New Frontier in Community Services: Residential Facilities for Developmentally Disabled Persons." Working Paper No. 72, Rehabilitation Research and Training Center in Mental Retardation. University of Oregon at Eugene. December, 1973.

01shansky, Simon and Beach, Dorothy. "A Five Year FollowUp of Mentally Retarded Clients." Rehabilitation Literature, XXXV (Feb., 1974), 48-49.

O'Neil, Lawrence. "Evaluation of Relative Work Potential: A Measure of Self-Concept Development." American Journal of Mental Deficiency, LXXII (1968), 614-619.

Perske, Robert. "About Sexual Development: An Attempt To Be Human with the Mentally Retarded." Mental Retardation, XI (Feb., 1973), 6-8.

Rosen, Marvin. "The Retardate in the Community: A PostInstitutional Follow-Up Study." Paper presented at annual meeting of American Association on Mental Deficiency, Denver, Colorado. May 15-20, 1967. 23 pp. Mimeo. 
Rosen, M.; Diggory, J.C.; Floor, Lucretia; and Nowakiwska, Myra. "Self-Evaluation, Expectancy, and Pefformance in the Mentally Subnormal." Journal of Mental Deficiency Research, XV (June, 1971), 81-95.

Rosen, Marvin; Floor, Lucretia; and Baxler, Donald. "Prediction of Community Adjustment: A Failure at CrossValidation." American Journal of Mental Deficiency, LXXVII (July, 1972), 111-112.

Rosen, Kivitz, Clark, and Floor. "Prediction of PostInstitutional Adjustment of Mentally Retarded Adults." American Journal of Mental Deficiency, LXXIV (1970), 726-734.

Saenger, G. "Social and Occupational Adjustment of the Mentally Retarded." in J. Zubin and G.A. Jervis (eds.) Psychopathology of Mental Development. New York: Grune and Stratton, 1967.

Shapiro, Helen. "Circle of Homes: Group Homes for the Retarded in Cuyohoga County." Mental Retardation, XI (June, 1973), 19-21.

Skaarbrevik, Karl. "A Follow Up Study of EMR in Norway." American Journal of Mental Deficiency, LXXV (1971), $560-565$.

Skarnvlis, Ed. "Noncitizen: Plight of the Mentally Retarded." Social Work, XIX (Jan., 1974), 56-62.

Smiley, Charles W. "The Advocacy Program." Perspectives in Psychiatric Care, X (1972), 220-225.

Snyder, Robert T. "Personality Adjustment, Self Attitudes, and Anxiety Differences in Retarded Adolescents.." American Journal of Mental Deficiency, LXXI (1966), 33-41.

Sparks, Howard L. and Younie, William J. "Adult Adjustment of the Mentally Retarded: Implications for Teacher Education." Exceptional Children, XXXVI (1969), 13-18.

Tarjan, G.; Wright, S.W.; Lyman, R.K.; and Keernan, C.V. "Natural History of Mental Retardation: Some Aspects of Epidemiology." American Journal of Mental Deficiency, LXXVII (1973), 369-379.

Tizard, Jack. "Research into Services for the Mentally Handicapped: Science and Policy Issues." British Journal of Mental Subnormality, XVIII (June, 1972), 6-17. 
Whitcraft, Carol J. and Jones, John D. "A Survey of Attitudes About Sterilization of Retardates." Mental Retardation, XII (Feb., 1974), 30-33.

Windle, Charles D.; Stewart, Elizabeth; and Brown, Sheldon J. "Reasons for Community Failure of Released Patients." American Journal of Mental Deficiency, LXVI (Sept., 1961). 
INTERVIEW GUIDE CHECKLIST

Number of jobs held

Working now? ___(yes)

(no)

Number of months working current job

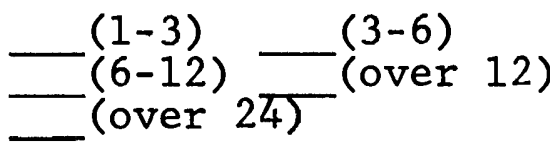

Like current job? (yes) (no)

How find new job? (indep.) (semi-indep.) (depend.)

Eat lunch alone? (yes) (no)

Flu question (indep.) (semi-indep.) (depend.)

Problem with other worker (yes/talk) (no/not talk)

How handle paycheck? __(indep.) _(semi-indep.) _(depend.)

Have hobbies? (yes) (no)

Go out in evening?

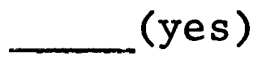
(no)

Tavern? (yes) (no)

Church? (yes) (no)

Clubs? (yes) (no)

Neighbors? (never) (seldom) (monthly) (week1y)

Friend in park? (yes) (no) See family? _(never) (lives with family) $^{(\text {(meldom) }}{ }^{\text {(month1y) _(weekly) }}$

Have special friend? (yes) (no)

Have boyfriend/girlfriend? (yes) (no) (married) Want to have children? (yes) (no)

Knowledge of birth control? _(none) _(some) _(functional) Knowledge of VD? _(none) _(some) _(functional) 


\section{INTERVIEW GUIDE}

Work

1. How did you get your first job?

2. How many jobs have you had since you have been in Portland?

3. What were they?

4. How long did you have your last job?

5. Why did you leave your last job?

6. When you first came to Portland, what type of job did you wish to find?

7. Where do you work now?

8. How long have you worked there?

9. How did you find this job?

10. What do you do at work?

11. Do you like what you do?

12. What do you like best about your job?

13. What don't you like about your job?

14. (if you don't like) Have you thought about getting a new job?

15. How would you find a new job?

16. What kind of new job would you like?

17. Where did you learn to do your job?

18. How do you get to work?

19. Where do you eat lunch?

20. Do you eat lunch by yourself?

21. (if eats with a friend) Do you see this person after work?

22. If you got the flu and had to stay home from work, what would you do about your job?

23. If you had a problem with another worker, what would you do?

24. Who would you talk to about this problem with another worker?

25. If your boss was in a bad mood, what would you do?

26. If you don't understand directions (give example according to person's job), what would you do?

27 . When do you get paid?

28. Do you get a check?

29. What do you do with your check once you get it?

30. Do many other people work where you do?

31. Do you know their names?

32. If you could have any job in the world. . .

33. The one thing I wish my boss would do is. . .

34. The hardest thing about my job is.. 
35. When I first started to work, the hardest thing was...

36. The best thing about my job is. .

37 . What things do you think make a good worker (rank)

a) working fast

b) on time

c) smiling

d) asking questions

e) following instructions

38. What do you think is important when you go to apply for a job?

39. What do you think is important in getting a job?

\section{Avocation}

1. After work, what chores do you have do to?

2. What do you do in the evening after the chores are done?

3. What do you do if it's raining?

4. Do you have any hobbies?

5. When did you start doing that?

6 . Who got you interested in that?

7. What else do you do for fun?

8. How often do you go out in the evening?

9. Is there a tavern in your neighborhood that you like? What is it called?

10. What do you do while you are there?

11. Is there a church in your neighborhood that you like?

12. How often do you go there?

13. What do you do while you are there?

14. Are there other places in this neighborhood that you like?

15. Do you belong to any clubs? When did you join it? How did you first find out about it?

16. What did you do last night after supper?

17. What did you do last weekend? With whom?

18. How do you usually find out about places to go after work or on weekends?

19. If you had two weeks off from work, what would you like to do?

20. Have you ever done that before?

21. If you met someone at work or at a park and liked them, would you see that person again? How would you do that?

22. Do you ever get a chance to talk with your neighbors? Do you like them?

Personal Relationships

1. How often do you see your family? How often would you like to see them?

2 . When you see your family, where do you usually get together? 
3. What does "a friend" mean to you?

4. Do you have a special friend?

5. What kinds of things do you do together?

6 . How often do you see each other?

7. How old is your friend?

8. How did you meet your friend?

9. Do you have a boyfriend/girlfriend? What's his/her name?

10. How long have you known him/her?

11. What do you like to do together? What did you do the last time you were together?

12. What do you like best about your boyfriend/girlfriend?

13. Is there anything you'd like to change about him/her?

14. How do you get a boyfriend/girlfriend?

15. What do you look for in a boyfriend/girlfriend?

16. Why do people think it's good to have a boyfriend/ girlfriend?

17. Do you think you are a good boyfriend/girlfriend?

18. Would you like to get married someday?

19. When do you think you might get married?

20. How does a person find someone to marry?

21. How would your life be different if you were married?

22. What would your perfect husband/wife be like?

23. Some people who are married have children and some do not. If you get married, do you want to have children?

24. If you don't want to have children (or not right away), how do you keep from having a baby? (to follow up) What do you mean? Where do you get that?

25. If you had a friend who had VD and he/she asked you what he/she should do about it, what would you tell him? (to be followed up depending upon answer). 
Organizations of parents and friends,

2. 10 help all the mentally retarded. wherever they are. regardless of ratit.

color. creed or age

Walter Fuhrer Executive Director
MULTNOMAH

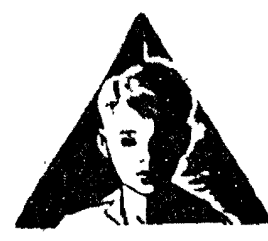

CLACKAMAS

\section{ASSOCIATIONS FOR RETARDED CITIZENS}

718 W. Burnside - Portland, Oregon 97209 - 223.7279

$$
\text { December } 16,1974
$$

TO WHOM IT MAY CONCERN :

Susan Kiley, Jeffrey Sher, and Richard Sunshine are graduate students at Portland State Univeraity (School of Social work), who are engaged in a research project in Portland. We are hopeful that the data they gather will be important for all of us who work in the community.

Dur Agency actively supports the work they are doing and requests your cooperation with them in this project. If you have any questions regarding the project, please contact Charlotte Duncan, 223-7279.

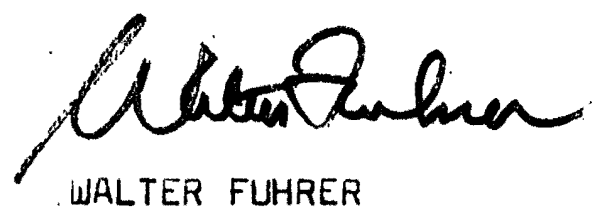

Executure Oriectar

$W F: m s$ 